PROBLEMS

OF EDUCATION IN THE $21^{\text {st }}$ CENTURY Vol. 79 , No. 6, 2021

880

\title{
INVESTIGATION OF USE CASES OF MATHEMATICS TEXTBOOKS IN THE TEACHING PROCESS FROM A DEVELOPMENTAL PERSPECTIVE
}

\author{
Nurullah Yazici \\ Karamanoğlu Mehmetbey University, Turkey \\ E-mail: yazicinurullah@gmail.com
}

\begin{abstract}
It is important to determine the behaviors of primary school pre-service teachers, who have successfully completed the "Mathematics Textbook Review" course during their undergraduate education, regarding the use of textbooks in their professional life. Therefore, it is important to determine the approaches of pre-service teachers who have positive ideas about using the mathematics textbook in their undergraduate education and the reasons for these approaches in the process after starting the profession. This research was designed with a developmental perspective from qualitative research approaches and was conducted with two different study groups in Turkey. The first study group consists of 162 primary school mathematics pre-service teachers. The second group consists of 43 primary school mathematics teachers who worked for at least two years in their professional life. As a result of the research, more than half of the preservice teachers $(n=132)$ stated that they would use textbooks as a basic resource in the in-class teaching process. Pre-service teachers' reasons for using the course book in the classroom teaching process were grouped under four categories: "it is a guide for teaching, homework, affordability, and opportunity for repetition". When the data obtained from the mathematics teachers were examined, it was determined that most of the teachers did not use the textbook as the main source in the classroom teaching process. When the obtained data are examined holistically, it is concluded that even though the rate of pre-service teachers thinking of using the textbook is high, this rate will decrease in professional life.
\end{abstract}

Keywords: Pre-service teachers, mathematics teacher, mathematics textbook, developmental perspective

\section{Introduction}

The use of materials is encouraged, especially in primary education, in order to enable students to better understand the concepts in mathematics and to increase their participation in the lesson (Kutluca \& Akın, 2014). Among these materials, textbooks with a usage rate of approximately $90 \%$ in mathematics lessons (Weiss, 1987) are concrete materials that direct teachers and students about what to do in the lesson. In this context, textbooks are the key point of the mathematics course, as they shape the teaching of mathematics (Nicol \& Crespo, 2006; Son, 2008). The textbook is accepted as a useful and economical tool in education, as it provides the students with integrated information about the units and subjects in the curriculum, provides them with the opportunity to repeat, reinforce, prepare for the exam and study at their own pace (Başer, 2012). In addition, textbooks are teaching tools that have an important place in all types of school systems, as they serve as a bridge between the teacher and the student (Altun et al., 2004).

The literature shows that textbooks significantly affect the content of mathematics lessons (Başer, 2012), shape teachers' ideas about mathematics, mathematics curriculum 
and mathematics teaching (Chavez-Lopez, 2003), and have a significant effect on students' mathematics learning status and mathematics achievement (Stylianides, 2009; Tarr et al., 2006; Van den Ham \& Heinze, 2018). The use of the textbook as an effective material in teaching mathematics encouraged researchers to work and many studies were conducted on the textbook. When the studies on the mathematics textbook are examined, it is seen that the studies are generally shaped as follows:

- On the purpose and frequency of the use of textbooks (Altun et al., 2004; Başer, 2012; Freeman \& Porter, 1989; Stodolsky, 1989; Zhu \& Fan, 2002);

- Evaluation of textbooks according to their features such as visual design, content, stylistic, language and expression (Dane et al., 2004; Nicol \& Crespo, 2006);

- Examining its suitability according to curricula or teaching strategies (Arslan \& Özpınar, 2009; Johansson, 2006; Santos et al., 2006);

- Comparative analysis of content, activities, practices, problems and exercises on the basis of countries (Aydın, 2010; Çelik \& Cinemre, 2012; Fan, \& Zhu, 2007; Haggarty, \& Pepin, 2002; Ildır1, 2009; Tutak \& Güder, 2012);

- Classification of the questions it contains according to mental development principles, cognitive levels, and mathematical proficiency levels (Katipoğlu \& Katipoğlu, 2016; Lepik et al, 2015; Özcan \& Erduran, 2018)

Studies on the use and frequency of textbooks have shown that teachers have different tendencies to use textbooks (Chavez-Lopez, 2003; El-Saleh, 2011; Freeman \& Porter, 1989; Kauffman, 2002; Zhu, \& Fan, 2002). Teachers' use of the textbook in the classroom teaching process seemed to be influenced by their mathematics content knowledge, grade level and pedagogical experience in teaching, as well as the number and variety of questions in the textbooks (Lepik et al., 2015; Mcnaught, 2009). It has been observed that these research studies are carried out only based on the opinions of teachers in a certain year of service. On the other hand, when we consider teachers' attitudes towards the use of mathematics textbooks as a process, it is important to evaluate this process from primary school years to university years. Because, in some studies conducted with teachers and students, it is revealed that teachers' active involvement of the textbook in the teaching process contributes positively to the level of students' use of the textbook.

It is thought that a study to determine the behaviors of primary school mathematics pre-service teachers who successfully completed the "Mathematics Textbook Review" course during their undergraduate education, regarding the use of textbooks in the classroom teaching process in their professional life, will contribute to the literature. Therefore, it is important to determine the approaches of pre-service teachers who have positive ideas about using the mathematics textbook in their undergraduate education and the reasons for these approaches in the process after starting the profession. In addition, determining the suggestions of those who do not actively use the textbook in the teaching process among the pre-service teachers who have officially started the teaching process is one of the problem situations of the research. In addition, from the perspective of experienced mathematics teachers, determining positive/ negative suggestions for the textbook is one of the aims of this research. For this purpose, answers to the following questions were sought:

1. How do primary school mathematics pre-service teachers' use of the textbook and their approach to the textbook change after they start the teaching profession?

2 . What are the suggestions of mathematics teachers regarding the content and usage of secondary school mathematics textbooks? 
PROBLEMS

OF EDUCATION

IN THE $21^{\text {st }}$ CENTURY Vol. 79, No. 6,2021

882

\section{Research Methodology}

\section{Research Model}

This research was designed with a developmental perspective from qualitative research approaches. Developmental research focuses on behavior. In other words, it is done in order to examine the changes and developments in the behavior of individuals over time (Hartmann et al., 2011). Developmental research studies are conducted under four headings: cross-sectional study, longitudinal study, cross-cultural study and Co-twin study (Van Herwegen, \& Riby, 2014). Since this research was conducted with different samples in the same time period, it was designed in the cross-sectional model, which is one of the developmental research types. In cross-sectional studies, a wide range of data can be reached in a short time, and historical and future data can be obtained (Cohen et al., 2007).

\section{Study Group}

This research was conducted with two different study groups in the Central Anatolian Region of Turkey. The first study group consists of 162 primary school mathematics pre-service teachers. The demographic characteristics of this group are as follows: To have successfully completed the "Mathematics Textbook Review" course conducted in the spring and fall semesters of a university in the Central Anatolian Region between 2017-2021. In the determination of this group, the criterion sampling method, one of the purposive sampling methods, was used. In criterion sampling, it is essential that the sample be composed of people, events, objects or situations with the qualities determined in relation to the problem (Emmel, 2013). Here, being a primary school mathematics pre-service teacher who has successfully completed the "Mathematics Textbook Review" course is taken as a criterion. Although the research data obtained from this group were collected in different time periods, it was assumed that it did not affect the design of the research since it was collected from different samples related to a single situation. Because studies examining different samples in different time periods are also considered as cross-sectional studies (Cohen et al., 2007).

The second group consists of 43 primary school mathematics teachers who worked for at least two years in their professional life and used the mathematics textbook for at least one year until the 2020-2021 academic year. In the creation of this study group, the criterion sampling method was adopted. As a criterion, it was required to have worked in the profession for two years and to have used any grade level mathematics textbook for at least one year.

Among the participants of the study, primary school mathematics pre-service teachers were coded as "TC1, TC2, ..., TC162", and primary school mathematics teachers were coded as "T1, T2, .., T43". Because in this way, it is aimed to give citations more easily and to comply with ethical rules. Within the scope of the research, the classified data regarding the professional seniority of primary school mathematics teachers are given in Table 1.

Table 1

Data on Primary School Mathematics Teachers

\begin{tabular}{lcc}
\hline Professional Seniority & Percent $(\%)$ & Frequency $(f)$ \\
\hline $2-6$ years & 32 & 14 \\
\hline $7-11$ years & 40 & 17 \\
\hline 12 years and above & 28 & 12 \\
\hline Total & 100 & 43 \\
\hline
\end{tabular}




\section{Data Collection Tools}

Semi-structured interview forms were used to collect the research data. In the data collection phase, interviews are used to collect data when it is not possible to collect data about the research with other data collection techniques (Wellington, 2000). For this purpose, two separate interview forms were prepared for primary school mathematics pre-service teachers and primary school mathematics teachers. In the interview form prepared for preservice teachers, they were asked to respond to the following statement with their reasons. "As a pre-service teacher, when I officially started my teaching job, I think/I do not think to use mathematics textbooks as the main resource in the in-class teaching process. Because...". Again, the pre-service teachers were also asked to what extent they encountered any textbook during the classroom learning process in their K-12 period student life.

Within the scope of the research, a textbook usage status interview form was applied to primary school mathematics teachers. Teachers were expected to explain the questions in the interview form along with their reasons. The following questions were asked to the teachers through the interview form:

1. I use/do not use mathematics textbooks as a basic resource in classroom teaching. Why is that?

2. Have you ever used the textbook in your previous teaching years? How long did you use it? Why is that?

3. What are your expectations from the secondary school mathematics textbook? Please explain.

Both interview forms were prepared by using the research studies in the literature with the help of document analysis technique in line with the purpose of the research. In order to check whether the research was prepared in line with its purpose, the opinions of three experts in the field of mathematics education were consulted. After having obtained approval from the expert opinions, the data collection phase was started. The process of collecting data from primary school mathematics pre-service teachers was completed in four years. At the stage when the data collection process from pre-service teachers was completed, data were started to be collected from primary school mathematics teachers. Data were collected from primary school mathematics teachers over a three-week period.

\section{Data Analysis}

Miles and Huberman (1994) stated that qualitative data analysis consists of three stages: data reduction, display, and conclusion. In qualitative data analysis, two types of analysis, descriptive and content analysis, can be made, although there are no systematic ways to agree on (Creswell \& Creswell, 2017). In the analysis of this research data, content analysis and descriptive analysis techniques were used in order to bring together the obtained data in groups and present them to the reader in an understandable way in tables. According to Patton (2002), content analysis can be carried out in two ways as deduction and induction. Deductive analysis includes the organization of data according to existing theory, while inductive analysis includes the process of forming theoretical categories from recurring ideas, behaviors, and emerging themes. In this study, inductive analysis was used in the analysis of the data obtained from both interview forms. In the research, firstly, it was determined under which themes the answers written by the participants to the questions in the interview forms should be presented. In this direction, the collected data were examined in depth and themes and codes were determined in line with the purpose of the research. In the next step, the answers were placed according to the determined themes, then the findings were defined and finally the findings were interpreted. Instead of giving all the citations for all the participants of the research, citations were used to reveal the studied situation. 
PROBLEMS

OF EDUCATION

IN THE $21^{\text {st }}$ CENTURY

Vol. 79, No. 6,202

884

In order to understand the findings more easily and concisely, the data were classified, and the research data were presented in percentage and frequency tables. In addition, the data were compared using a timetable in order to examine the development more easily in the research. Percentage and frequency techniques, which are descriptive analysis techniques, were used in the presentation of the tables.

\section{Validity and Reliability}

Guba and Lincoln (1982) discussed the quality criteria for qualitative research in education in four categories: credibility (validity), dependability (reliability), confirmability and transferability. In this research, more than one data collection technique was used by diversifying with document analysis, interviews and direct quotations to ensure credibility. In addition, the fact that the researcher actively conducts the "Mathematics Textbook Review" course and meets the participant pre-service teachers and teachers, although the time changes, will also increase the credibility in the interpretation and interpretation of the collected data. It is also thought that these situations will decrease the Hawthorne effect and increase the credibility (Sedgwick \& Greenwood, 2015; Smith, \& Coombs, 2003).

Dependability is about whether the researcher conducts the research process appropriately and carefully. Therefore, the research method should be consistent with the researchers and the data collection techniques used in the research process over time (Miles \& Huberman, 1994; Robson, 1993). In this research, diversification was tried to be made and the steps followed in the research process, participants, context and method were tried to be defined clearly. Giving detailed information about the basic stages of the research and the position and approach of the researcher is one of the measures that will increase the dependability in qualitative studies (Guba, \& Lincoln, 1982).

In order to ensure confirmability, data collection methods and processes and data analysis were clearly defined, and enough raw data were presented to the reader by making direct quotations to support the findings. In addition, information was given about data collection tools and development processes. The direct goal of qualitative research is not generalizability. However, in this study, the number of participants was kept high, allowing a natural generalization process.

Ethical principles oversight has been adopted throughout the current research. Before starting the research, the participants were promised that their names would not be revealed anywhere (Cohen et al., 2007), that they would not be harmed in any way, and that their privacy and shared secrets would be protected (Drew et al., 1996). And these points were complied with throughout the research. The principles of scientific research and publication ethics were followed in the process of establishing the theoretical framework of the study, collecting data, analyzing, and interpreting the data. References to other publications in the study were made in accordance with scientific rules.

\section{Research Results}

Within the scope of the first problem of the research, firstly, the data obtained about the pre-service teachers are included. When examined the approaches of primary school mathematics pre-service teachers to the point of using textbooks, more than half of the preservice teachers $(n=132 ; 81 \%)$ stated that they will use textbooks as a basic resource in the in-class teaching process. However, some of the pre-service teachers $(n=19 ; 12 \%)$ stated that they were not sure about using/not using it, while the rest $(n=11 ; 7 \%)$ stated that they did not intend to use it. Table 2 contains statistical information about the data obtained from pre-service teachers. 
Table 2

Information on Pre-service Teachers' Use of Textbooks

\begin{tabular}{lcc}
\hline Using the Textbook & Percent (\%) & Frequency (f) \\
\hline I am considering using it. & 81 & 132 \\
\hline I am not considering using it. & 7 & 11 \\
\hline I am not sure. & 12 & 19 \\
\hline Total & 100 & 162 \\
\hline
\end{tabular}

Based on the findings in Table 2, it is seen that pre-service teachers' attitudes towards using textbooks throughout their undergraduate education are generally positive. Pre-service teachers' reasons for using the textbook in the classroom teaching process were concentrated in four categories. These categories are as follows: "to be a guide for teaching, to be able to do homework, to be economical, to provide opportunity for repetition". As a matter of fact, similar results will be seen when the statements of pre-service teachers are examined. Some of the quotes from the pre-service teachers are given below:

TC2: As a pre-service teacher, I intend to use mathematics textbooks in the classroom teaching process when I started teaching and throughout my teaching life. Because textbooks guide us. In other words, it is a helpful resource on how we will advance the course, what we will talk about and what kind of examples we should give.

TC5: I'm considering using it. Because the textbook allows me to prepare for the lesson in the first years of my profession. In addition, I think the information in its content is reliable. I plan to use it again by supporting it with additional resources in the following years.

TC9: I plan to use it when I start teaching. Because I believe that textbooks will guide me in order to explain the subjects in order, which method and technique to use, and to find examples. In addition, I think that I will use it in the following years of my teaching, since it is economical and accessible materials.

When the quotations above are examined, it can be said that although no such distinction was made by the researcher in the interview form, the pre-service teachers divided the way they used the textbook into processes as the first years of teaching and the following years. In the first years of teaching, it is seen that there is a tendency to refer to the textbook in order to explain the subjects in order, to find examples and to help in the context of pedagogical content knowledge. In the later years of the teaching profession, it is seen that there is a tendency towards the textbook, based on the fact that it is economical and accessible materials or the necessity of benefiting from additional resources.

Table 3

Opinions of Pre-service Teachers about Using Only Textbooks in the Teaching Process

\begin{tabular}{lcc}
\hline Using Only the Textbook & Percent (\%) & Frequency (f) \\
\hline It is sufficient to use only the textbook. & 65 & 86 \\
\hline It is not sufficient to use only the textbook. & 35 & 46 \\
\hline Total & 100 & 132 \\
\hline
\end{tabular}


PROBLEMS

OF EDUCATION

IN THE $21^{\text {st }}$ CENTURY Vol. 79, No. 6,2021

When Table 3 is examined, some of the pre-service teachers who stated that they would use the textbook in the teaching process $(n=46 ; 35 \%)$ stated that they did not want to stick to the textbook alone. As the reason for this situation, pre-service teachers stated that there are incorrect and incomplete definitions and notations in the textbooks, some subjects are very superficial, and the variety and number of questions is insufficient. The same reasons were also encountered in the pre-service teachers who did not want to use the textbook during the in-class teaching process. Some of the quotes from the pre-service teachers are given below:

TC16: Textbooks will provide convenience in my teaching life. For this reason, I will use it. However, in the later stages of teaching, supplementary books can be used alongside textbooks by making use of additional resources.

TC22: I intend to use the textbooks actively. However, I think that it should be supported with supplementary source books in order to increase the variety of questions.

TC27: Even though the textbook is a guide in many points, together with the central exams, it is not enough. I find it insufficient in terms of the number and variety of examples and types of activities.

TC31: I intend to use it. However, I think that it would be more efficient to not only stick to the textbook, but also to support it with auxiliary resources. This is how I can improve my question variety, activity types, methods and techniques.

TC45: I will use textbooks throughout my teaching, but I think I can enrich my teaching with helpful resources. For this reason, I will use the supplementary resources and the textbook together.

It is also seen in the quotations above that the reasons of pre-service teachers who consider using the textbook in the teaching process but do not find it sufficient or do not intend to use it at all are similar to each other.

Within the scope of the first problem of the research, when examined the data obtained on primary school mathematics teachers, Table 4 shows first the use of the textbook by mathematics teachers throughout the teaching profession.

Table 4

Data on the Duration of Primary School Mathematics Teachers Using the Textbook throughout the Teaching Profession

\begin{tabular}{lcc}
\hline Periods of Using the Textbook & Percent (\%) & Frequency (f) \\
\hline I've never used. & 16 & 7 \\
\hline I used one semester. & 12 & 5 \\
\hline I used it for 1 year. & 44 & 19 \\
\hline I used it for 2 years. & 16 & 7 \\
\hline I used it for 5 years. & 12 & 5 \\
\hline Total & 100 & 43 \\
\hline
\end{tabular}

When the data in Table 4 are examined, it is seen that primary school mathematics teachers use the textbook for a part of their professional life very little or not at all. In addition, based on the data of the interviews with the teachers, it was determined that the textbooks were widely used especially in the first years of the profession to follow the subject, to find examples and to get pedagogical help in the context of determining methods and techniques. However, in the following years, it was observed that textbooks were not used in the teaching process. 
When the reasons for this situation were examined, it was seen that the mathematics teachers stated that the variety and number of examples was insufficient, the new generation questions were very few compared to the central exams, and the textbooks were not compatible with the smart board. Below are quotations regarding the reasons why mathematics teachers do not use the textbook:

T2: I used it only in the first year of my professional life. It was useful in terms of subject tracking and practicality of giving examples. I didn't use it later. (He has 7 years of professional seniority.)

T5: Since the number of questions is few and there is no diversity, I only used it in the first two years of my professional life. I didn't use it afterwards. (He has 13 years of professional seniority.)

T9: I remember using it for almost five years. It was especially effective in giving homework. However, the changing exam systems started to be insufficient due to the new generation questions. I am not currently using it. (She has 9 years of professional seniority.)

T24: When I started my profession, I used it for a period of time. After that I stopped using it. Because central exams have pressure on students. In this edition, he directed me to resources containing a variety of questions and current questions. (She has 4 years of professional seniority.)

T32: I can say that I have never used textbooks. I think additional resources include richer question types. (He has 3 years of professional seniority.)

When the above quotations are examined, it is seen that the reasons for using the course book by the pre-service teachers are not valid reasons for using the course book by the mathematics teachers. Therefore, it can be said that the practices of pre-service teachers who intend to use the textbook in their professional life and mathematics teachers are in contrast. Because the reasons given by the pre-service teachers for using the textbook were not found in the statements of the mathematics teachers continuing their profession.

Table 5 is included in the research in order to examine the data obtained from preservice teachers and primary mathematics teachers more easily and to present the development regarding the use of textbooks in a general approach. When Table 5 is examined, it is seen that the use of textbooks is according to certain seniority of teaching starting from the preservice teacher stage. According to Table 5, it can be said that there is a tendency not to use the textbook in the classroom teaching process as the professional seniority of teaching increases. It is observed that the data in Table 5 have similarities with the quotations obtained from primary mathematics teachers and pre-service teachers in terms of the approach to using the textbook. 
Nurullah YAZICI. Investigation of use cases of mathematics textbooks in the teaching process from a developmental perspective

PROBLEMS

OF EDUCATION

IN THE $21^{\text {st }}$ CENTURY Vol. 79, No. 6,2021

Table 5

Development of Pre-service Teachers and Primary School Mathematics Teachers' Use of Textbooks Over Time

\begin{tabular}{|c|c|c|c|c|c|c|c|c|c|c|c|c|}
\hline & \multicolumn{2}{|c|}{$\begin{array}{l}\text { Pre-service } \\
\text { teacher }\end{array}$} & \multicolumn{2}{|c|}{$\begin{array}{l}\text { 1-year } \\
\text { professional } \\
\text { seniority }\end{array}$} & \multicolumn{2}{|c|}{$\begin{array}{l}2 \text { years } \\
\text { professional } \\
\text { seniority }\end{array}$} & \multicolumn{2}{|c|}{$\begin{array}{l}5 \text { years } \\
\text { professional } \\
\text { seniority }\end{array}$} & \multicolumn{2}{|c|}{$\begin{array}{l}\text { 6-10 years } \\
\text { professional } \\
\text { seniority }\end{array}$} & \multicolumn{2}{|c|}{$\begin{array}{l}11 \text { and above } \\
\text { professional } \\
\text { seniority }\end{array}$} \\
\hline & $(\%)$ & (f) & (\%) & (f) & (\%) & (f) & (\%) & (f) & (\%) & (f) & (\%) & (f) \\
\hline $\begin{array}{l}\text { I am } \\
\text { considering } \\
\text { using it. / } \\
\text { I use. }\end{array}$ & 82 & 132 & 81 & 9 & 64 & 7 & 42 & 5 & 17 & 1 & 0 & 0 \\
\hline $\begin{array}{l}\text { I am not } \\
\text { considering } \\
\text { using it./ } \\
\text { I did not } \\
\text { use it. }\end{array}$ & 6 & 11 & 19 & 2 & 36 & 4 & 58 & 7 & 83 & 5 & 100 & 3 \\
\hline I am not sure. & 12 & 19 & - & - & - & - & - & - & - & - & - & - \\
\hline Total & 100 & 162 & 100 & 11 & 100 & 11 & 100 & 12 & 100 & 6 & 100 & 3 \\
\hline
\end{tabular}

When Table 5 is examined, it is seen that the majority of pre-service teachers have a tendency to use the textbook. On the other hand, although primary mathematics teachers are prone to use the textbook in the teaching process in the first years of the profession, it can be said that there is a tendency to move away from the textbooks in the following years. This result can be interpreted as that as teachers' professional seniority increases, they turn to alternative resources instead of textbooks or they shape the teaching process in the context of their own competencies. As a matter of fact, the quotations regarding the reasons why mathematics teachers do not use the textbook confirm this situation.

In line with the second problem of the research, it was aimed to reveal the expectations of primary school mathematics teachers regarding the content and usage situations of mathematics textbooks. In this context, when the findings were examined, it was observed that all primary school mathematics teachers had expectations that the variety of questions should be increased. In addition, it has been determined that teachers have basic expectations in the form of workbooks containing new generation question types suitable for central exams and resource books containing rich teaching methods and techniques suitable for smart boards. Expressions similar or close to this finding were also observed in the expressions of pre-service teachers. Below are quotes about the expectations of primary mathematics teachers from the mathematics textbook:

T21: The variety of questions should definitely be increased. In addition, the number of questions from exercises and problems should be increased.

T22: The number of questions should be increased. Each topic should have at least 200 questions. Or additional question books should be prepared. Current question types should be included.

T27: It should be made suitable for smart boards. In other words, while students are following the book during the lesson, teachers should be able to open the content on the smart board and write something on it.

T31: There must be workbooks next to the course book. Otherwise, the textbook alone is not enough. Especially in terms of the number and variety of questions.

When we examine the above statements, it is seen that it is important to revise the secondary school mathematics textbooks in line with the expectations of primary school 
mathematics teachers and pre-service teachers and make their content more qualified and useful. Again, it can be said in the context of the above quotations that the reasons for the teachers who do not use the mathematics textbook and the expectations of the teachers from the textbooks are parallel to each other.

\section{Discussion}

As a result of the research, it was observed that pre-service teachers were more inclined to the idea of using the textbook in the classroom teaching process. On the other hand, it has been observed that mathematics teachers who continue their profession are generally not inclined to use the textbook in the teaching process. This finding differs from the result of the study by Weiss (1987). Weiss (1987) stated that the rate of use of textbooks in the teaching process is approximately $90 \%$. The reason for this difference can be explained as the fact that mathematics teachers choose reality, taking into account the goals and expectations of students, as a result of staying between ideality and reality. In other words, it can be said that pre-service teachers emphasize ideality more as a result of their desire to experience textbooks, since they are not yet in the profession. In addition, the fact that mathematics teachers wanted to include different teaching materials and source books in the in-class teaching process may have brought about this result. As a matter of fact, in the studies conducted, it has been determined that textbooks are generally an important source for teachers, but they are not seen as the only source, so different sources should be included (Fan et al., 2004; Zhu \& Fan 2002). In addition to this result, the fact that mathematics textbooks do not adequately meet the expectations of teachers is thought to be an important factor in teachers' not preferring the textbook in the classroom teaching process. Because there are many statements in the research findings that mathematics teachers need to develop secondary school mathematics textbooks. Among these expressions, in the context of content, it is thought that the diversity and low number of questions that take into account individual developments in the textbooks stand out as the situations that need to be improved in terms of mathematics textbooks. Similar results have been found in many studies in the literature (Kocaoğlu Er, 2016; Mutu, 2008; Turan, 2019). In addition to the variety of questions, the expectations of mathematics teachers from the secondary school mathematics textbook can be expressed as follows:

- It should be the primary source to be consulted and studied in preparation for the exams,

- The number and variety of questions in the new generation question style should be increased,

- It should be made suitable for smart boards and technological developments,

- There should be workbooks as additional resources for students and guidebooks for teachers.

When we evaluate the results above, it can be interpreted that the suppressive feature of the central exams as well as the fact that the textbooks are not suitable for technological equipment adversely affect the use of the textbook. As a matter of fact, in the studies conducted, it has been observed that teachers generally exhibit a negative attitude towards the thought that mathematics textbooks encourage the use of technology and help teachers in creating an efficient learning-teaching environment (Katipoğlu \& Katipoğlu, 2016; Turan, 2019).

When the data obtained from primary school mathematics pre-service teachers are examined in the research, it is seen that the rate of thinking of using the textbook in the classroom teaching process is high. On the other hand, this rate is very low for mathematics teachers. When we examine the data of both groups together, it can be said that the rate of preservice teachers using the textbook will decrease in the process after starting the profession, that is, there will be a change in the tendency not to use the textbook in the teaching process. Because, it has been observed that mathematics teachers actively use the textbook in the 
PROBLEMS

OF EDUCATION

IN THE $21^{\text {st }}$ CENTURY Vol. 79, No. 6,2021

890

classroom teaching process in the first years of their profession. On the other hand, it was determined that mathematics teachers turned to supplementary source books after the second and third years of the profession. Therefore, these findings also confirm this result. In some of the studies revealing the use of the textbook in the teaching process of mathematics teachers, it was observed that the teachers used the textbook effectively (Chavez-Lopez, 2003; Son, 2008), while in some studies it was observed that the teachers did not use the textbook effectively (Iş1k, 2008; Santos et al., 2006). In some studies, it has been observed that teachers are not completely dependent on the textbook and use the textbooks when they deem it necessary for the lesson (Altun et al., 2004; Sosniak \& Stodolsky, 1993).

\section{Conclusions and Implications}

In this study, it was revealed that pre-service teachers had a positive attitude towards using the textbook in the teaching process throughout their undergraduate education. When we examine the mathematics teachers, it was observed that while they approached the textbook positively in the first years of the profession, they tended to move away from the textbook as the professional seniority increased. Therefore, this study revealed that pre-service teachers are more inclined to the idea of using textbooks in the classroom teaching process compared to teachers. This situation can be interpreted as pre-service teachers will move away from the textbook after starting their profession. The data obtained from the teachers also confirm this result. When we examined these data, mathematics teachers stated that the number and variety of questions in the textbooks were low. They also revealed that it should be prepared in source books in addition to textbooks. Therefore, teachers' opinions can be consulted frequently in order to prepare a more qualified and efficient textbook. In addition, in future studies, the reasons for teachers who continue their profession to move away from the textbook can be examined in detail.

The existence of central exams is another problem for teachers to move away from the textbook. It is a situation desired by both society and family for students preparing for central exams to be familiar with different types of questions by solving more questions. In this case, teachers will both take into account the goals and expectations of the students and will want to use the textbook in the teaching process. This result creates a dilemma for teachers. In this study, it was revealed that teachers moved away from the textbook and turned to additional resources. Within the scope of these results, it is thought that it is a necessity to prepare auxiliary resources in preparation for central exams in addition to textbooks.

In this study, it was also revealed that the content of the textbooks is insufficient in terms of technology-based activity. It is obvious that this situation will cause teachers to not benefit from the textbook sufficiently. For this reason, while preparing the content of mathematics textbooks, it may be preferred that they encourage mathematics teachers to use more technology and guide their teaching activities.

\section{Limitations}

Since this study is developmental research, it is limited to primary school mathematics pre-service teachers and primary school mathematics teachers in a city in the Central Anatolian Region of Turkey. In addition, the fact that the study focused only on the use of the mathematics textbook in the classroom teaching process is another limitation. In this context, it can be said that there is a need for more research on the use of textbooks in the national and international context. 


\section{References}

Altun, M., Arslan, Ç., \& Yazgan, Y. (2004). Lise matematik ders kitaplarının kullanım şekli ve sıklığı üzerine bir çalışma [A study on the usage and frequency of high school mathematics textbooks]. Uludağ Üniversitesi Eğitim Fakültesi Dergisi, 17(2), 131-147. https://dergipark.org.tr/en/ download/article-file/153239

Arslan, S., \& Özpınar, İ. (2009). İlköğretim 6. sınıf matematik ders kitaplarının öğretmen görüşleri doğrultusunda değerlendirilmesi [Evaluation of primary school 6th grade mathematics textbooks in line with teacher opinions]. Dicle Üniversitesi Ziya Gökalp Eğitim Fakültesi Dergisi, 12, 97113. https://dergipark.org.tr/en/pub/zgefd/issue/47955/606752

Aydın, İ. (2010) Sekizinci sınıf matematik ders kitabı hakkında öğretmen ve öğrenci görüşleri [Evaluation of the 8 th class mathematics literature textbook from the perspective of teachers and students]. (Unpublished Master Dissertation), Zonguldak Karaelmas University, Zonguldak.

Ball, D. L., \& Feiman-Nemser, S. (1988). Using textbooks and teachers' guides: A dilemma for beginning teachers and teacher educators. Curriculum Inquiry, 18(4), 401-423. https://doi.org/10.1080/036 26784.1988.11076050

Başer, N. (2012). İlköğretim öğretmenlerinin matematik ders kitaplarını kullanma yolları ve onların ögrencilerin matematik ders kitapların kullanma yolları ve matematik ders kitabı hakkindaki görüssleri [A case study of elementary mathematics teachers'views of their and students'textbook usage and of mathematics textbooks' characteristics]. (Unpublished Master Dissertation). Middle East Technical University, Ankara.

Chavez-Lopez, O. (2003). From the textbook to the enacted curriculum: textbook use in the middle school mathematics classroom. (Unpublished Doctoral Dissertation). The Faculty of the Graduate School University of Missouri, Columbia.

Cohen, L., Manion, L., \& Morrison, K. (2007). Research methods in education (6th Ed.). RoutledgeFalmer.

Creswell, J. W., \& Creswell, J. D. (2017). Research design: Qualitative, quantitative, and mixed methods approaches. Sage publications.

Çelik, D., \& Cinemre, Y. (2012). İlköğretim 8. sınıf matematik ders kitabının eğitimsel tasarımına ilişkin öğretmen ve uzman görüşleri [The opinions of teachers and experts on the educational design of the primary school 8th grade mathematics textbook]. Milli Eğittim Dergisi, 194, 216-239. https:// dergipark.org.tr/en/pub/milliegitim/issue/36174/406747

Dane, A., Doğar, Ç., \& Balkı, N. (2004). İlköğretim 7. sınıf matematik ders kitaplarının değerlendirmesi [The evaluation of the primary education seventh grade mathematics textbooks]. Erzincan Eğitim Fakültesi Dergisi, 6(2), 1-18. https://dergipark.org.tr/en/pub/erziefd/issue/5994/79754

Drew, C. J., Hardman, M. L., \& Hart, A. W. (1996). Designing and conducting research: Inquiry in education and social science. Allyn \& Bacon.

El-Saleh, İ. K. (2011). Teacher's concerns regarding the adaption of the new mathematics textbook. (Unpublished doctoral dissertation), Texas State University, America.

Emmel, N. (2013). Sampling and choosing cases in qualitative research: A realist approach. Sage Publications.

Fan, L., \& Zhu, Y. (2007). Representation of problem-solving procedures: A comparative look at China, Singapore, and US mathematics textbooks. Educational Studies in Mathematics, 66, 61-75. https://doi.org/10.1007/s10649-006-9069-6

Freeman, D. J., \& Porter, A. C. (1989). Do textbooks dictate the content of mathematics instruction in elementary schools? American Educational Research Journal. 26(3), 403421. https://doi.org/10.3102/00028312026003403

Guba, E. G., \& Lincoln, Y. S. (1982). Epistemological and methodological bases of naturalistic inquiry. Educational Communication and Technology Journal (ECTJ), 30, 233-252 https://doi.org/10.1007/BF02765185

Haggarty, L., \& Pepin, B. (2002). An investigation of mathematics textbooks and their use in English, French and German classrooms: Who gets an opportunity to learn what?. British Educational Research Journal, 28(4), 567-590. https://doi.org/10.1080/0141192022000005832 
PROBLEMS

OF EDUCATION IN THE $21^{\text {st }}$ CENTURY Vol. 79, No. 6,2021

Hartmann, D. P., Pelzel, K. E., \& Abbott, C. B. (2011). Design, measurement, and analysis in developmental research. In M. H. Bornstein \& M. E. Lamb (Eds.), Developmental science: An advanced textbook (pp. 109-197). Psychology Press.

Ildırı, A. (2009). İlköğretim beşinci sınıf matematik ders kitabında ve öğrenci çalışma kitabında yer alan problemlerin incelenmesi ve bu problemlere ilişkin ögretmen görüşlerinin belirlenmesi [The investigation of problems in the fifth-grade mathematics textbook and study book of students of the primary education and the definition opinions of the teachers about these problems]. (Unpublished Master Dissertation). Cukurova University.

Işı, C. (2008). İlköğretimin ikinci kademesinde matematik öğretmenlerinin matematik ders kitabı kullanımını etkileyen etmenler ve beklentileri [The factors affecting the use of mathematics textbook of mathematics teachers at primary education grades 6-8 and their expectations]. Kastamonu Eğitim Dergisi, 16, 163-176. https://dergipark.org.tr/en/pub/kefdergi/issue/49101/626569

Johansson, M. (2006). Textbooks as instruments: Three teachers' ways to organize their mathematics lessons. Nordic Studies in Mathematics Education, 11(3), 5-30.

Katipoğlu, M., \& Katipoğlu, S. (2016). Matematik öğretmenlerinin öğrenci ders kitabı hakkındaki görüşleri [Mathematıcs teachers' opinions about student course book]. Uluslararası Eğitim Bilim ve Teknoloji Dergisi, 2(3), 156-165. https://dergipark.org.tr/tr/pub/uebt/issue/26733/281497

Kauffman, D. (2002). A search for support: Beginning elementary teacher's use of mathematics curriculum materials. Project on the Next Generation of Teachers at the Harvard Graduate School of Education. https://datascience.iq.harvard.edu/files/gse-projectngt/files/kauffman_aera2002.pdf

Kocaoğlu Er, F.S. (2016). İlköğretim matematik öğretmenlerinin 5. ve 6. sinıf matematik dērs kitaplarına ilişkin görüşleri [Primary education mathematic teachers' opinions on $5^{\text {th }}$ and $6^{\text {th }}$ grade course books] (Unpublished Master Dissertation). Gazi University, Ankara.

Kutluca, T., \& Akın, M. F. (2014). Dört kefeli cebir terazisi somut materyali yardımı ile tamsayılar konusunun ögretimi [Teaching the subject of integers with the help of four head algebra scale concrete material]. Illkögretim Online, 13(1), 17-26. https://core.ac.uk/download/pdf/230034139. pdf.

Lepik, M., Grevholm, B., \& Viholainen, A. (2015). Using textbooks in the mathematics classroom - the teachers' view. Nordic Studies in Mathematics Education, 20(3-4), 129-156. http://ncm.gu.se/ wp-content/uploads/2020/06/20_34_129156_lepik.pdf

Mcnaught, M. D. (2009). Implementation of integrated mathematics textbooks in secondary school classrooms (Unpublished doctoral dissertation). University of Missouri.

Miles, M. B., \& Huberman, A. M. (1994). Qualitative data analysis: An expanded sourcebook. Sage publications.

Mutu, B. B. (2008). Teachers'opinions about mathematics textbooks of 6th and 7th grades. (Unpublished Master Dissertation). Department of Elementary Education of University of Osmangazi, Eskişehir.

Nicol, C. C., \& Crespo, S. M. (2006). Learning to teach with mathematics textbooks: How preservice teachers interpret and use curriculum materials. Educational Studies in Mathematics, 62(3), 331355. https://doi.org/10.1007/s10649-006-5423-y

Özcan, Ö., \& Erduran, A. (2016). Lise matematik ders kitaplarının öğretmen görüşlerine göre incelenmesi: 10. Sınıf örneği [Investigation of high school mathematics textbooks according to teachers' views: the 10th class sample]. Uluslararası Bilimsel Araştırmalar Dergisi (IBAD), 3(2), 933-959. https://doi.org/10.21733/ibad.475459

Patton, Q, M. (2002). Qualitative evaluation and research methods. Sage publications.

Robson, C., (1993). Real word research: A resource for social scientists and practitioner-researchers. BlackWell Publishers.

Santos, D., Cruz, J., \& Macías, G. (2006). Expectations vs. reality of the use of mathematics textbooks in elementary schools. Annual meeting of the North American Chapter of the International Group for the Psychology of Mathematics Education, Mexico 798-804. http://citeseerx.ist.psu.edu/viewdoc/ download? doi $=10 \cdot 1 \cdot 1 \cdot 687.8094 \&$ rep $=$ repl\&type $=$ pdf\#page $=936$

Sedgwick, P., \& Greenwood, N. (2015). Understanding the Hawthorne effect. Bmj, 351:h4672 https://doi.org/10.1136/bmj.h4672

Smith, I. D., \& Coombs, S. J. (2003). The Hawthorne effect: is it a help or a hindrance in social science research?. Change (Sydney, NSW), 6(1), 97-111. https://search.informit.org/doi/10.3316/ielapa.200307649 
Son, J. (2008). Elementary teachers' mathematics textbook use in terms of cognitive demands and influential factors: a mixed method study. (Unpublished Doctoral Dissertation). Michigan State University, Michigan.

Sosniak, L. A., \& Stodolsky, S. S. (1993). Teachers and textbooks: Materials use in four fourth-grade classrooms. The Elementary School Journal, 93(3), 249-275. https://doi.org/10.1086/461725

Stodolsky, S. S. (1989). Is teaching really by the book? In P.W. Jackson \& S. Haroutunian-Gordon (Eds.), From Socrates to software: The teacher as text and the text as teacher. (pp. 159-184). University of Chicago Press.

Stylianides, G. J. (2009). Reasoning-and-proving in school mathematics textbooks. Mathematical Thinking and Learning, 11(4), 258-288. https://doi.org/10.1080/10986060903253954

Tarr, J. E., Chávez, Ó., Reys, R. E., \& Reys, B. J. (2006). From the written to the enacted curricula: The intermediary role of middle school mathematics teachers in shaping students' opportunity to learn. School Science and Mathematics, 106(4), 191-201. https://doi.org/10.1111/j.1949-8594.2006.tb18075.x

Turan, E. (2019). 9. Sinif, fizik, kimya ve biyoloji ders kitaplarında yer alan etkinliklerin bilimsel sorgulama açısından incelenmesi [Examining the activities in $9^{\text {th }}$ grade physics, chemistry and biology textbooks in terms of scientific inquiry.] (Unpublished Master Dissertation). Marmara University, İstanbul.

Tutak, T., \& Güder, Y. (2012). İlköğretim 5. sınıf öğretmenlerinin matematik ders kitabı hakkındaki görüş ve düşünceleri [The opinions of the primary $5^{\text {th }}$ grade school teachers' views about mathematics textbook]. Dicle Üniversitesi Ziya Gökalp Ë̌itim Fakültesi Dergisi, 19, 16-28. https://dergipark. org.tr/en/pub/zgefd/issue/47945/606593

Van den Ham, A.K., \& Heinze, A. (2018). Does the textbook matter? Longitudinal effects of textbook choice on primary school students' achievement in mathematics. Studies in Educational Evaluation, 59, 133-140. https://doi.org/10.1016 / j.stueduc.2018.07.005

Van Herwegen, J., \& Riby, D. (2014). Neurodevelopmental disorders: Research challenges and solutions. Psychology Press.

Weiss, I. R. (1987). Report of the 1985-86. National survey of science and mathematics education. Research Triangle Institute, https://files.eric.ed.gov/fulltext/ED292620.pdf

Wellington, J. (2000). Educational research: Contemporary issues and practical approaches, Continuum. Zhu, Y., \& Fan, L. (2002). Textbook use by Singaporen mathematics teacher at lower secondary school level. Journal for Research in Mathematics Education, 21(2), 98-108. https://eprints.soton. ac.uk/179999/

Received: October 07, 2021

Accepted: November 29, 2021 